\title{
"All Americans are hero-worshippers": American Observations on the First U.S. Visit by a Reigning Monarch, 1876
}

\author{
By Phil Roberts, University of Wyoming
}

When Dom Pedro II, emperor of Brazil, visited America in 1876, he planned to assess industrial and technological innovation on display at the Centennial Exposition in Philadelphia and to pay visits to men whom he admired. Most Americans were fascinated by the emperor, even though his visit came at an awkward time. During the centennial of the Declaration of Independence, America was hosting an emperor-and from the last major slaveholding country. This article reviews newspaper accounts of the visit and analyzes the ambivalence displayed toward his visit. Americans were supposedly devoted to equality. Nonetheless, wherever he went during his three-month sojourn, the emperor was met by admiring crowds. One newspaper explained: "It is not the monarch so much as the novelty that attracts in this country." This article views the visit not from Dom Pedro's impressions of America, but from American responses to the visit of a hereditary monarch-the first to travel around America during his reign. The paper concludes that centennial-year fascination with toyalty generally overcame historic contempt for hereditary privilege and lack of interest in royal visitors. Such ambivalent attitudes toward visiting royalty continue into the present day.

Thousands of Europeans and foreigners from elsewhere in the world traveled about America in the nineteenth century and wrote down their impressions of what they had seen. Many such accounts appeared in newspapers in their home countries or showed up in book form for readers curious about America and things American. ${ }^{1}$ Historians draw from these writings both a sense of what foreigners thought about the United States and how they interpreted American life to their fellow citizens in Europe and elsewhere. ${ }^{2}$ This study takes the opposite tack, however. It examines American commentary on a visiting foreigner, Emperor Dom Pedro II of Brazil, who came to the United States during the 1876 Centennial

${ }^{1}$ Famous examples include Sir Richard F. Burton, who was less than complimentary about much that he saw in his The City of the Saints, and across the Rocky Mountains to California (New York, 1862); Charles Wentworth Dilke, Greater Britain: A Record of Travel in English-Speaking Countries During 1866-67 (New York, 1869); and Louis Simonin, Le grand-ouest des Etats-Unis (Paris, 1869), translated and portions republished as Simonin, The Rocky Mountain West in 1867 (Lincoln, NE, 1966). One celebrated travel account by an American that was popular in Europe is Mark Twain, Roughing It (Hartford, 1872).

${ }^{2}$ See, for instance, David M. Wrobel and Patrick T. Long, eds., Seeing and Being Seen: Tourism in the American W'est (Lawrence, KS, 2001). A classic on tourism in the U.S. West is Earl S. Pomeroy, In Search of the Golden West: The Tourist in Western America (1957; Lincoln, NE, 1990).

Journal of the Gilded Age and Progressive Era 7:4 (October 2008) 
Exposition. What did American observers say about what he saw, how various groups of people viewed him, where he traveled, and what he told his hosts about the places he had seen? In learning what Americans wrote about this celebrity visitor, one also learns about how Americans thought of themselves in the centennial year of American independence. From the numerous accounts of Dom Pedro's visit, one sees how journalists reassured themselves and their readers as to America's belief in egalitarianism and its rejection of hereditary rule.

In the twenty-first century, American tabloid journalists still gain readership by reporting on the comings and goings of "the royals." Even though the foibles, excesses, and pronouncements of hereditary monarchs rarely amount to matters of state, even the mainstream press contains regular accounts of royal lives. The phenomenon is hardly modern. Observers have long commented on American ambivalence toward royalty. The attitudes have ranged from adoration and envy to bemused contempt. As James Bryce noted in the late nineteenth century, there already existed a tendency in America to "relish and make the most of such professional or official titles as can be had; it is a harmless way of trying to relieve the monotony of the world." But he also added, "If there be, as no doubt there is, less disposition than in England to run after and pay court to the great or the fashionable, this is perhaps due not to any superior virtue, but to the absence of those opportunities and temptations which their hereditary titles and other social institutions set before the English." 3

American ambivalence toward royalty was made obvious in 1876, the onehundredth anniversary of independence, when there was an opportunity for many Americans to see, up close, a ruling monarch. For the first time, the country played host to a ruling emperor. To help commemorate the centennial of the Declaration of Independence, the United States hosted Brazil's Dom Pedro, reigning monarch of the last major slaveholding empire in the world. ${ }^{4}$ To many Americans, bewildered by rapid industrialization and social upheavals resulting from immigration and the fall of the institution of slav-

3 James Bryce, American Commonwealth, 2nd ed. rev. (London, 1891), 2:624-25.

${ }^{4}$ Dom Pedro II ruled as a constitutional monarch. He became emperor at the age of five in April 1831, following the abdication of his father, Dom Pedro I. Many members of the royal family had been in Brazil since 1808, when they were forced to flee Portugal during the Napoleonic Wars to Brazil, ostensibly ruling both countries from the New World colony. In 1822, Brazil gained independence from Portugal, and Dom Pedro I agreed to serve as constitutional monarch. Ongoing tensions between the ruler and the Chamber of Deputies forced his abdication in 1831 and departure for Portugal, with his daughter (sister of Dom Pedro II) who later became queen of Portugal. For a summary of political events leading up to Dom Pedro II's rule and the early tumultuous years of his reign, see two chapters in Leslie Bethell, ed., Cambridge History of Latin America, vol. 3 (New York, 1985): Bethell and Jose Murilo de Carvalho, "Brazil After Independence," and Richard Graham, "Brazil from the Middle of the Nineteenth Century to the Paraguayan War." 


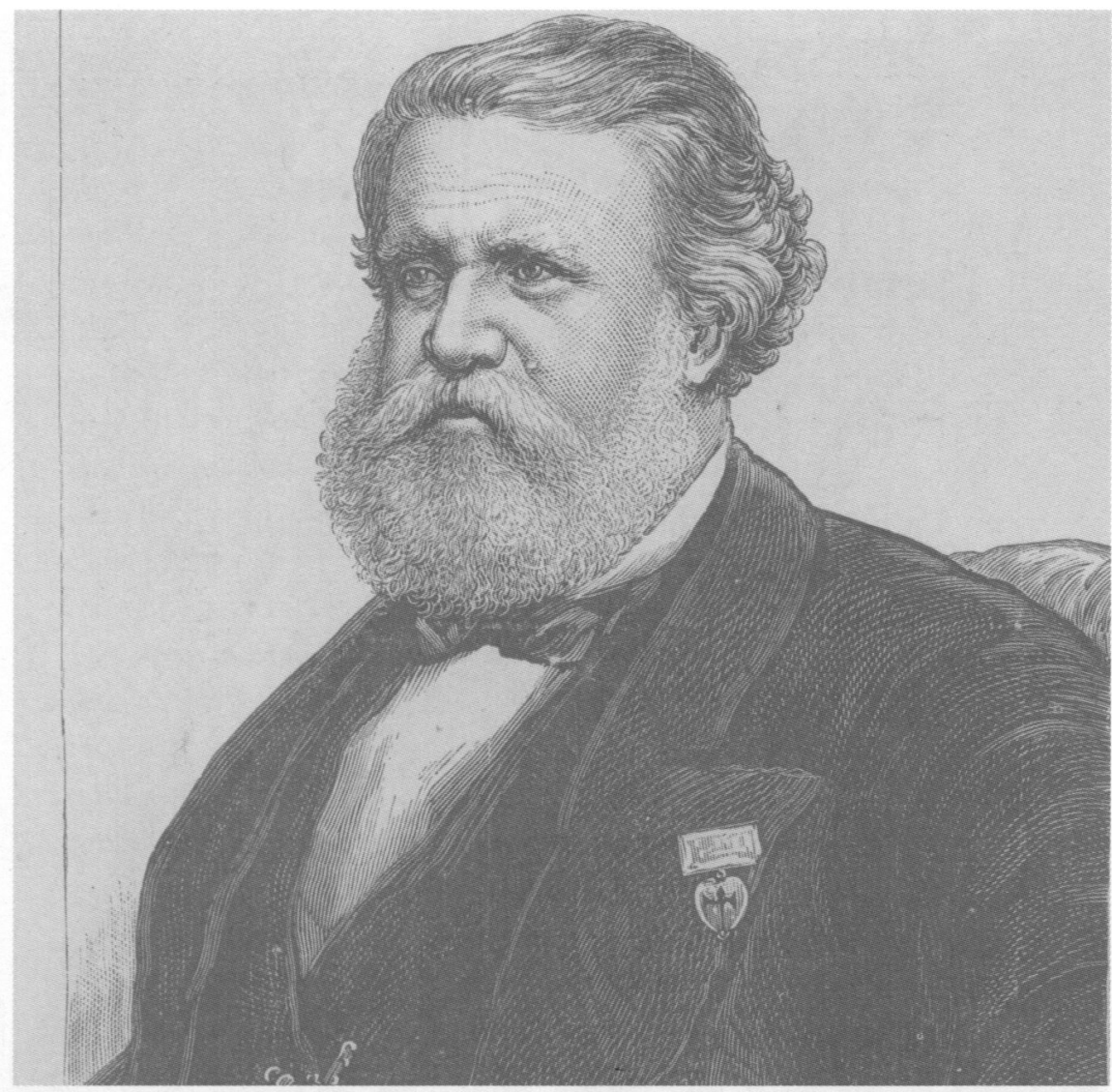

Emperor Dom Pedro II of Brazil. From Frank Leslie's Historical Register of the United States Centennial Exposition (New York, 1876).

ery, this first-ever visit by a royal head of state to the United States assuaged their yearnings for the stability offered by hereditary leadership confirmed in the person of an enlightened monarch. Some simply viewed the visit as a matter of curiosity. To others, it was an awkward intrusion of an antiegalitarian symbol at a time when the country was celebrating the anniversary of independence from another empire. Indeed, Dom Pedro was an anomalya hereditary monarch in the "New World," not from the corrupt and sinful "Old World" of Europe. ${ }^{5}$

Newspaper commentary from the period reflects diverse, often contradictory feelings about monarchy. Analysis of news coverage demonstrates that southerners, for instance, viewed such spectacles differently from individuals living in the West. While discussion of "royalty" was injected in strained,

${ }^{5}$ Edmund Morgan recently provided a reminder that the Declaration of Independence was not generally "anti-monarchical" but specifically opposed to the "present monarch of Great Britain." Edmund S. Morgan, "Inventing the Liberal Republican Mind," New York Reriew' of Books, Nov. 16, 2006. 


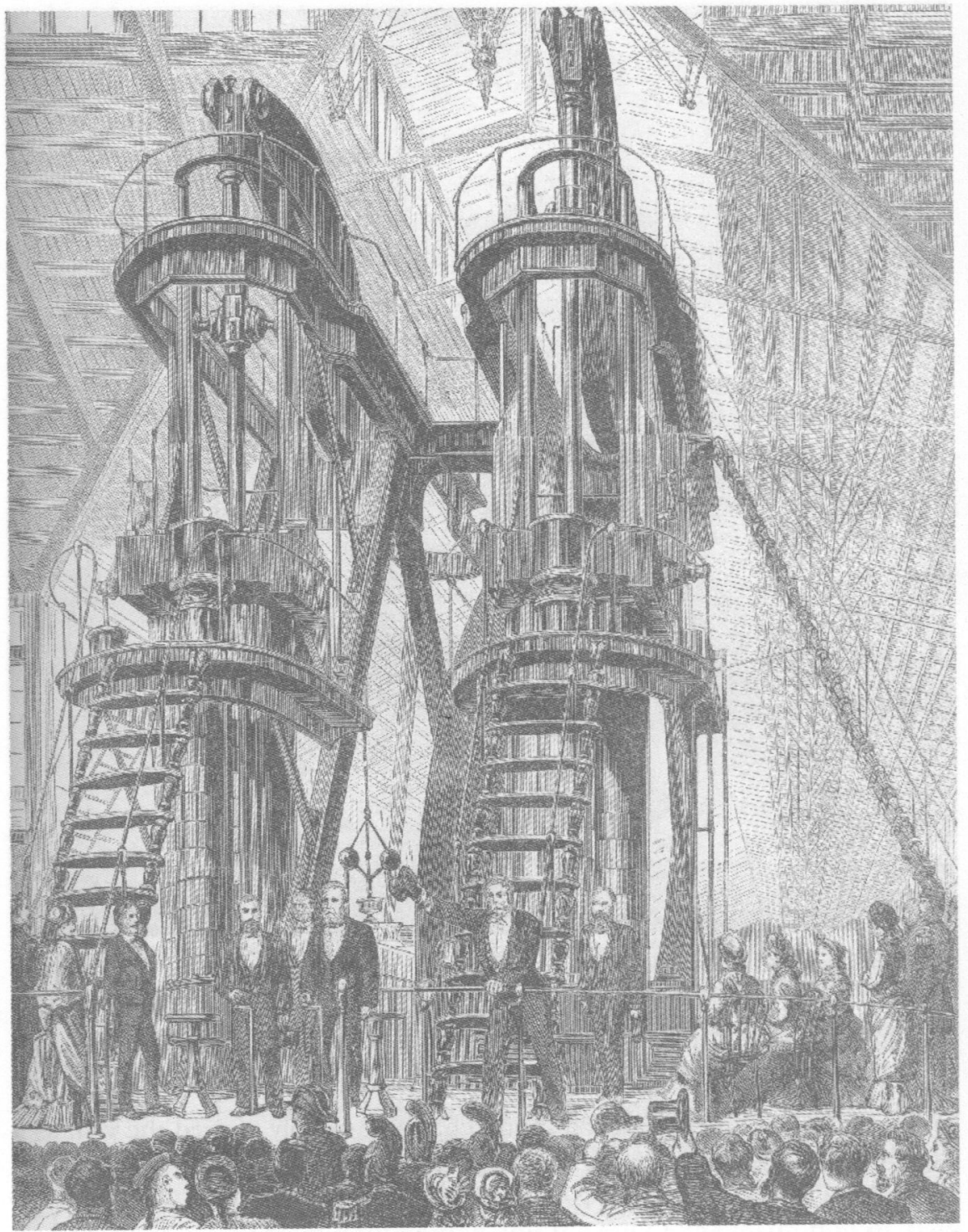

"President Grant and the Emperor of Brazil Starting the Great Corliss Engine in Machinery Hall," Frank I estie's Historical Register of the United States Centernial Exposition, 79.

predictable ways into partisan politics, many editors made a real attempt to explain the ambivalent welcome Americans gave to this royal personage. Not only was Dom Pedro an emperor, he brought with him other characteristics that worried various segments of the American public. He was the hereditary head of a slaveholding nation, a Catholic, and to some degree an intellectual. ${ }^{6}$ Moreover, he was a promoter of Brazilian products, particular-

${ }^{6}$ The best biography of Dom Pedro II is Roderick J. Barman, Citizen Emperor: Pedro II and the Making of Brazil, 1825-91 (Stanford, 1999). According to Barman, Pedro viewed himself as "agent for the spread of 'civilization' (European culture) in Brazil" (118). 


\section{The Emperor's Itinerary:}

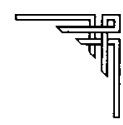

April 16: Dom Pedro arrives in New York; stays two days and leaves for the Midwest and the West Coast.

April 21: Dom Pedro makes a brief stop in Chicago.

April 24: Dom Pedro visits the Mormon Tabernacle in Salt Lake City.

April 25: Dom Pedro begins visit in San Francisco.

May 3: Dom Pedro returns from the West, passing through Wyoming and Nebraska on the train.

May 10: Dom Pedro attends the opening of the Centennial Exposition, Philadelphia.

May 22: Dom Pedro visits Washington, D.C.

Last week in May: Dom Pedro travels to the Midwest (Cincinnati) and then to the South by train to New Orleans and to Atlanta on May 30. First half of June: Dom Pedro visits New England, visiting with numerous writers and scientists and stopping at Harvard.

June 25: Dom Pedro visits Philadelphia Exposition; views Bell demonstration.

Early July: Dom Pedro departs the United States for Europe and the Middle East, visiting Syria and Egypt before returning to Brazil late in the year.

ly cotton and tobacco, that competed with American products on the world market. Each fact was distasteful to sizable numbers of Americans, most of whom had never seen an emperor and probably never dreamed they would.?

Despite the purpose of the Centennial Exposition, organizers of the Philadelphia-based celebration invited Dom Pedro, and he accepted.

7Barman, Citizen Emperor, 275-80, makes only brief references to the U.S. tour. The most complete narrative account of Dom Pedro's visit is Mary Wilhelmine Williams, Dom Pedro the Magnanimous: Second Emperor of Brazil (Chapel Hill, 1937), ch. 10. Unfortunately, the Williams account makes many laudatory generalizations based on rather weak evidence. For instance: "He was probably the most popular foreigner that has ever been in the United States" (209). Much of her narrative derives from the extensive coverage of the trip done by the New York Herald. The paper's correspondent, James O'Kelley; joined the emperor on ship when he left Brazil. By the time the party went west, newspapers named O'Kelley as part of the emperor's entourage. Therefore, one may question whether O'Kelley's impressions were entirely unbiased. This article does not cite the Herald, except to the extent that other newspapers commented on its dispatches about Dom Pedro's trip. Among newspapers consulted for my study were dailies in Atlanta, New Orleans, New York, Chicago, and on the West Coast. These include the New York Evening Post, New York Times, Frank Leslie's Illustrated Newspaper, Chicago Tribune, Atlanta Constitution, San Francisco Chronicle, Pacific Appeal (San Francisco), Oregonian (Portland), Washington Standard (Olympia), Cheyenne Daily Leader, Sidney (Neb.) Telegraph. 
Neither event is surprising. Dom Pedro was interested in world's fairs. He apparently had a role in preparing Brazilian exhibits for the Paris exhibition in the previous decade. ${ }^{8}$ Even more important, he was curious about American industry and admired American ingenuity. The centennial committee, like many Americans at the time and since, displayed a certain curiosity toward royalty. While dismissing the institution of a royal family as against all principles of equality, they seemed fascinated by hereditary rulers. Further, the presence of a royal visitor promised to provide a certain international legitimacy to the event.

Remarking upon this ambiguity, the editor of the New York Times wrote: "It must be confessed that our people do not entertain a very high reverence for Kings and Emperors, as Kings and Emperors go. A monarch so liberal, enlightened, and practical as Dom Pedro, however, must command the respect of all sensible men." The Chicago Tribune noted, "All Americans are hero-worshippers. It is our failing. As plain republicans, we do a great deal of useless running after royalty, and the citizen of this remarkable country who can sit near a Royal Highness at a dinner sits on the top round of the ladder of happiness." 10 Another-editor argued, "It is not the monarch so much as the novelty that attracts in this country. Jenny Lind or the Prince of Wales, Japanese Tommy or one of the Grand Dukes of Russia, King Kalakaua or Blind Tom, alike make a sensation for the hour, and then their day has passed."11 The editor of Frank Leslie's suggested that Dom Pedro was such a sensation because, even though he was royalty, in terms of his character and personality, he showed the qualities of a typical American. "Among the distinguished foreign visitors to the Centennial," Frank Leslie's commemorative book explained, "the Emperor and Empress of Brazil were of all the most notable and most observed. The assiduity and perseverance [with] which Dom Pedro made himself acquainted with the character of the Exhibition and the nature of its contents recommended him constantly to those under whose observation he came, the possessor of these peculiarly American qualities being naturally an object of interest in this country."12

Huge crowds turned out to greet Dom Pedro on his U.S. tour, with its itinerary set to end with his appearance at the Philadelphia celebration. He was, after all, the first reigning emperor of a major country ever to visit the

${ }^{8}$ Louis Agassiz mentioned seeing the Brazilian exhibit for the Paris fair in 1865 when the "Amazonian products" were being brought together in Para, Brazil, in preparation for the event. Louis and Elizabeth Agassiz, A Journey in Brazil (1867; Boston, 1896), 510.

${ }^{9}$ Nen' York Times, Apr. 17, 1876.

${ }^{10}$ Chicago Tribune, Apr. 18, 1876, p. 4.

"Frank Leslie's Iliustrated Neuspaper, Apr. 22, 1876, p. 106.

${ }^{12}$ Frank Norton, ed., Frank Leshie's Historical Register of the L'nited States Centennial Exposition, 1876 (New York, 1877), 299, 301. 


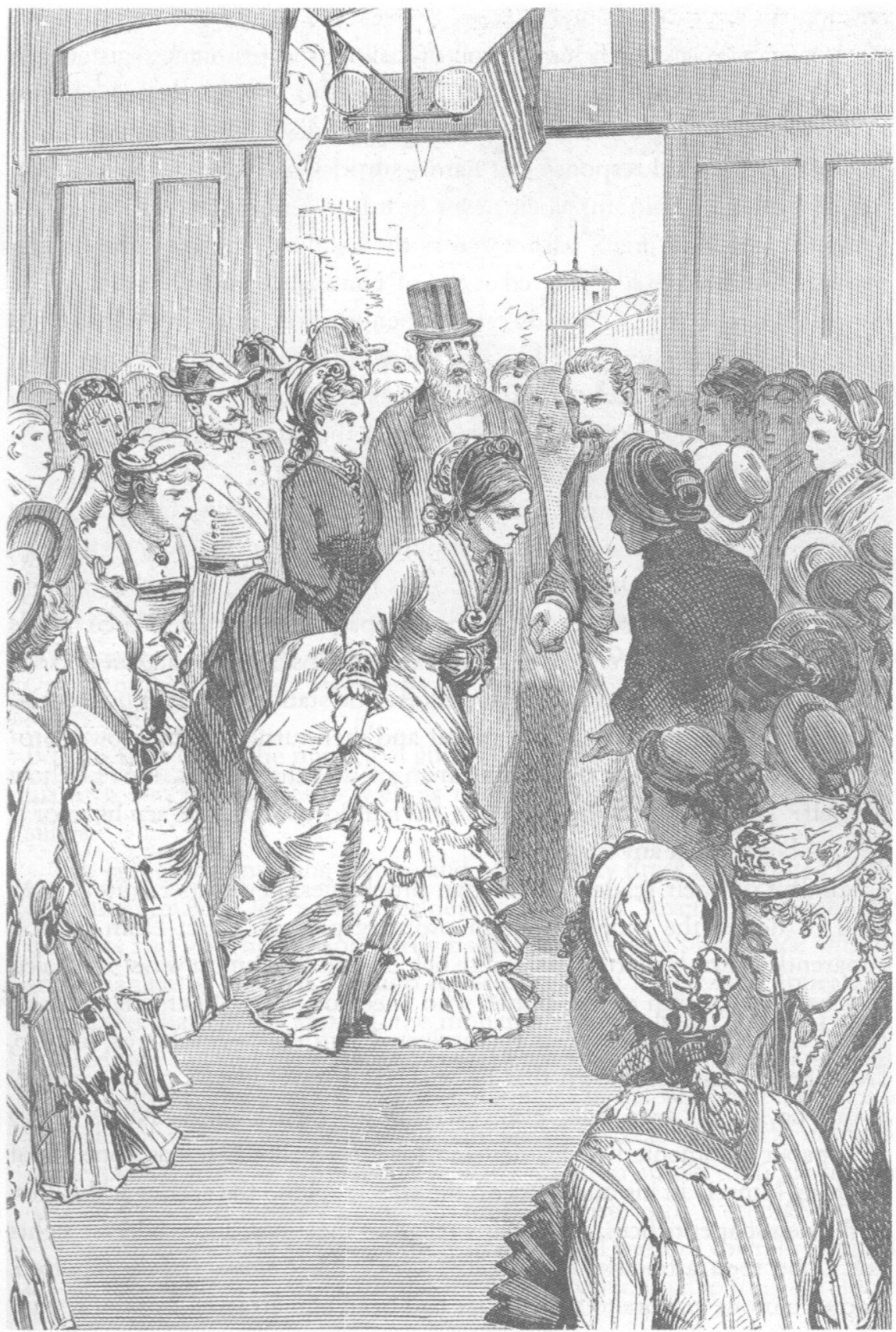

"Reception of the Emperor and Empress of Brazil in the Women's Pavilion," Frank Leslie's Historical Register of the United States Centennial Exposition, 81.

United States. When the emperor's train passed before dawn along the Baltimore and Ohio route east of Chicago, thousands lined the tracks to get a glimpse of the famous visitor. "May be curiosity entered largely into the 
reasons, for early rising potentates are scarce," the Chicago Tribune explained. An elected official, "with his fist full of ballots and his name registered in four different wards," is insignificant compared to a "man elected by birth to the highest office in his nation," the Tribune added. The newspaper concluded that the local response was hardly surprising: "When a live emperor, full of health and bloom, albeit never heard of before and not altogether perfect in the local lingo, flashes across the country, it is not unbecoming, perhaps, that he should be stared at out of continence and cheered at till he is deaf."13 It was not just a midwestern phenomenon, however. When Dom Pedro was touring the South, his train passed through a small Georgia town before the sun rose. "Although the hour was early, quite a number of ladies and gentlemen were at the depot to see him," the Atlanta Constitution reported. The writer made no effort to explain the interest. ${ }^{14}$

Despite the outpouring of interest, Americans indeed displayed a mixture of curiosity and ambivalence about royalty throughout the emperor's threemonth visit. En route to San Francisco, his train stopped at several stations. "Many, more venturesome than their companions...flattened their noses against the glass doors endeavoring to catch glimpses of the august personage," the San Francisco Chronicle reported. At one station, a farmer unsuccessfully tried to enter the emperor's railcar and then turned to the crowd, proclaiming, "He's no better than a poor man an' why the dickens don't he show himself?" Another person yelled out, "What do you want to see him for if he's no better than any man?"15

Mindful of their readers' egalitarian proclivities, newspaper editors tried hard to depict the monarch as an ordinary person. Here, Dom Pedro's apparently down-to-earth personality helped. His "common ways" appealed to a broad spectrum of the public who liked to see royal personages seem for all the world as average as themselves. From the beginning of his trip, Dom Pedro made it known that he wished to travel like "a private gentleman," paying his own bills, even carrying his own luggage. Nearly every newspaper commented on his demand for informality. "He has gone about enjoying himself in his quiet way on the street, behind the scenes at theatres, in the newspaper offices, at Moody's religious meetings, and wherever sights are to be seen attractive to Brazilian eyes," the Chicago Tribune reported. Earlier famous visitors to some cities had been embarrassed by minor scandals. The Chicago paper continued, "Least of all, did he care to subject himself to the annoyance of having his bills flung in his face, as happened to poor King Kalakaua [of Hawaii] in New York and President Grant in

${ }^{13}$ Chicago Tribune, Apr. 20, 1876, p. 8.

14 Atlanta Constitution, May 31, 1876, p. 2.

${ }^{15}$ San Francisco Cbronicle, Apr. 26, 1876, p. 8. 


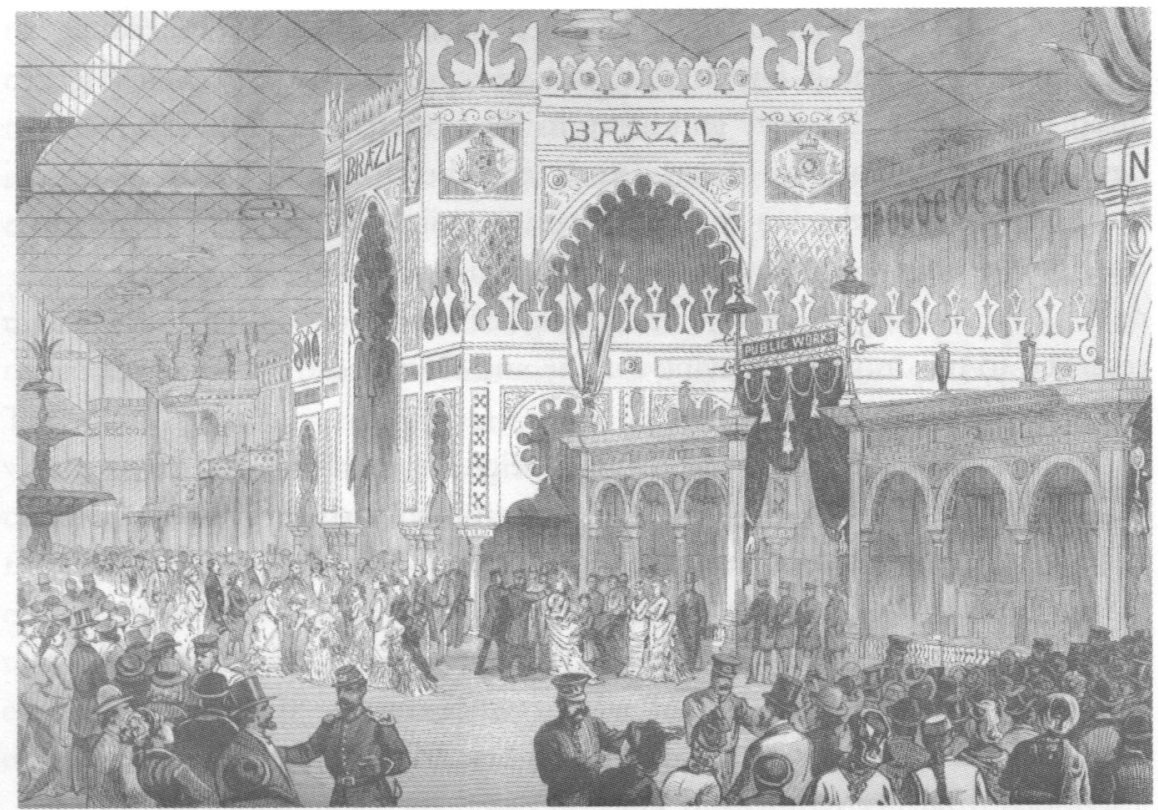

"The Emperor and Empress of Brazil Visiting the Brazilian Department on the Day of the Opening of the Exposition," Frank Leslie's Historical Register of the United States Centennial Exposition, 83.

Boston after being the municipal guests." 16 Other papers noted that he paid his own way to theatres as well as insisting on paying for his own hotel suites. ${ }^{17}$

The emperor's imposing stature and his ordinary dress contributed to the egalitarian image. One newspaper described him as "over six-feet tall, gray whiskers and gray haired and partly bald. He dresses in plain black without any ornament at all."18 A Chicago reporter detailed his physical appearance and noted that "in his apparel, the monarch seems a little careless. He was dressed in a full suit of black, the coat a little shiny at the lapels, and pants a little baggy at the knees. There were wrinkles in his vest, as if he were in the habit of sinking his hands in his pantaloons pockets."19 He was not what one expected from an emperor. "He walks about in an old drab hat instead of a crown and flourishes a gingham umbrella instead of a scepter." 20

The emperor's train stopped briefly in one small western town in the middle of the night. A reporter for the local newspaper, unable to get an inter-

${ }^{16}$ Chicago Tribune, Apr. 18, 1876, p. 4.

${ }^{17}$ New York Times, Apr. 16, 1876, p. 1; Boston Evening Transcript, June 9, 1876, p. 1.

18 Atlanta Constitution, Apr. 30, 1876, p. 4, c. 1. A similar description appeared in the Boston Eiening Transcript, Apr. 21, 1876, p. 4.

${ }^{19}$ Chicago Tribune, Apr. 20, 1876, p. 8.

${ }^{20}$ Atlanta Constitution, May 16,1876 , p. 2. The paper also compared him in appearance to "a Kentucky farmer"; May 9, 1876, p. 1. 
view from the sleeping monarch, nonetheless gave an eyewitness account of the "meeting": "The [Cheyenne Daily] Leader reporter was permitted to gaze upon His Sleeping Majesty and listen to the imperial snore, which may be described - the snore we mean-as a cross between the sonorous nosebuster of the bull-whacker and the quivering wail which issues from the proboscis of a lovely woman when her bronchial tubes are affected by a bad cold." After the reporter had a brief look, the train moved on. The reporter returned to his duties, "believing that he and Don Pedro would never meet again." 21

American cities had never hosted a reigning monarch, so newspapers offered suggestions about how the emperor should be greeted. In San Francisco, the newspaper lectured their readers to avoid "vulgar display." The paper said his reception should "consist of a thorough cleansing of the streets, a modest display of bunting, both American and Brazilian; a respectful deference...; the avoidance of all unseemly rushing after and gazing at him; a polite readiness to show him sights...and avoidance of obtrusive attentions of every nature and kind." 22 Later, the same paper warned San Franciscans to "let him arrive in quiet and proceed without disturbance to his hotel. He will appreciate such a reception vastly more than the hooting of an excited crowd." 23

The purpose of the emperor's visit was to learn more about America, one newspaper stressed. "If he is to be hurried from town to town by festive circles of aldermen, dined within an inch of his life by common councils and boards of freeholders, forced to review straggling armies of militia, and otherwise bored to death by petty officeholders, the effect will be fatal," warned Frank Leslie's Illustrated Newspaper. "A monarch of his years and dignities needs to be greeted by the gravest of our sages and most weighty of our untitled citizens," the paper concluded. ${ }^{24}$

Boston editors intimated that crowds did not interrupt his appearances there. Their lack of interest prompted the Boston Evening Transcript to ask, "Do the people of Boston realize the fact that they have a live emperor among them, who is engaged in 'seeing the sights' as though he was no more a sovereign than the average American citizen?" Elsewhere in the same issue, however, a report of his arrival in Lowell and Salem indicated that his visit was not being taken lightly. "Large numbers of people gathered" along the route from Montreal, the Transcript reported, "and on arrival [in Boston],

${ }^{21}$ Cheyenne Daily Leader, May 3, 1876, p. 3. The general tone of coverage by small western papers indicates less of a reverence for the royal personage; see also the Sidney (Neb.) Telegraph, May 6, 1876.

22 San Francisco Chronicle, April 23, 1876, p. 4.

${ }^{23}$ Ibid., April 25, 1876, p. 2.

${ }^{24}$ Frank Leslie's Illustrated Newspaper, April 22, 1876, p. 106. 
the party entered the side door of the Revere House" to avoid the large crowd in front. ${ }^{25}$ The press unanimously saluted his absence of kingly pretension. The Transcript editorialized after his visit, "He has avoided publicity in every way. No wonder Brazil is so fond of an emperor who has so just a claim to the higher title of a true gentleman."26

The pattern for informal receptions was set by Dom Pedro's unpretentious arrival in New York in mid-April 1876. He avoided the pomp of the official greeting planned for him on his arrival at the port of New York. Three U.S. cabinet secretaries set out on an American warship to greet the visiting notable and escort him onto the American vessel for a ceremonial cruise up the Hudson River to the docks. The three men boarded the English commercial vessel on which Dom Pedro had sailed from Brazil as one of more than fifty paying passengers. The emperor greeted them courteously, but he reminded them that he was not making an official trip. "The emperor is in Brazil; I am only a private Brazilian citizen," he told them, declining to change ships. ${ }^{27}$

Newspapers nationwide reported how his decision confused those who had expected to impress him with speeches and band music. Most papers characterized the official greeters as "stuffed-shirts" and unfavorably compared them to the emperor who had no love for ceremony. According to the Chicago Tribune, the cabinet officers had long-winded welcomes prepared. "Some potentates enjoy it; some do not, and among the latter is Dom Pedro." When Dom Pedro interrupted the speeches, the Tribune gleefully noted that "with laconic brevity he saved himself a narrative of the glories of Brazil, of the progress of America." 28 The American ship, sans emperor, received salutes from the batteries and other ships as it passed up the Hudson while the commercial British vessel carrying the monarch made its way up the East River without fanfare. "The ludicrous mistake" was not noticed until the American ship had docked and officials, red-faced over the musical salute played by a military band, explained Dom Pedro's absence to the assembled crowd. ${ }^{29}$

Throughout his travels, he spurned official greetings. When he came to Lowell to inspect the textile mills there, "the mayor attempted to meet him at the Northern depot, but his train went on to the Merrimack depot" instead, the Boston newspaper noted. ${ }^{30}$ In California, Dom Pedro boarded

${ }^{25}$ Boston Evening Transcript, June 9, 1876, pp. 1, 4.

${ }^{26}$ Ibid., June 10, 1876, p. 4.

${ }^{27}$ New York Tïmes, Apr. 16, 1876, p. 1.

${ }^{28}$ Chicago Tribune, Apr. 18, 1876, p. 4.

${ }^{29}$ New York Times, Apr. 16, 1876, p. 1 . The Times added another insult to the welcoming committee by quoting an observer who called it the "worst salute I have ever heard. It would be a disgrace to a merchantman."

${ }^{30}$ Boston Etening Transcript, June 8, 1876, p. 1. 
an earlier train which avoided the huge crowds at the stations. When his scheduled train appeared at Oakland, "there was a double file of Oakland brass-banders...awaiting the signal for the initiatory burst of a serenade," the newspaper reported. When it was discovered that the emperor was not aboard, "as the train moved off, the passengers remarked an array of brass instruments held in the air so as to conceal the blushes of the ardent musicians."31

In San Francisco, "a great crowd waited for the regular train, bands were playing and colors flying." Dom Pedro, who had arrived an hour earlier, was resting in his suite at the Palace Hotel, which he had entered through a side door. 32 An editor summarized the view observers had of his reluctance to take center stage: "[He displayed] so rare a course of conduct, even in these days of disillusion of royalty...even though his own persistence in his privacy may severely test our generous courtesy." 33

Not everyone was pleased with Dom Pedro's successful attempts to avoid formal receptions. "It is never easy to say precisely how much is meant by the pious fraud of an incognito," wrote William Cullen Bryant, the editor of the New York Evening Post. Bryant, without mentioning that he was one of the "official greeters" for the city of New York, added that there was "no reason" for not giving the emperor a friendly welcome. He questioned whether it was "absolutely necessary that the emperor should decline to be brought to the city in a naval vessel detailed for that purpose." 34 In San Francisco, Dom Pedro scheduled a tour of the Exchange but canceled when he was told of the huge crowds awaiting him. "He did not appear, to the disgust of the assembled crowd," the press reported. 35

While newspapers debated the emperor's modest evasion of the formal reception, many snickered at the embarrassed officials who had tried to formalize the emperor's arrival. Among such notables were the three cabinet officers-Secretary of State Hamilton Fish, Secretary of War Alphonso Taft, and Secretary of the Navy George M. Robeson-who were the victims of Dom Pedro's snub at New York harbor. In an obvious, politically motivated dig at the national officials, the Atlanta Constitution bluntly stated: "He has given the American people a severe but needed lesson in the noble art of how not to make asses of themselves." 36

${ }^{31}$ San Francisco Chronicle, Apr. 26, 1876, p. 8.

32The Oregonian (Portland), April 24, 1876, p. 1. The only mention of Dom Pedro made by a black-owned San Francisco newspaper noted that he was staying at the Palace Hotel while he visited the city; Pacific Appeal (San Francisco), April 22, 1876, p. 2.

${ }^{33}$ San Francisco Chronicle, Apr. 17, 1876, p. 4.

${ }^{34}$ New York Evening Post, Apr. 17, 1876, p. 2.

${ }^{35}$ Wire report noted in the Oregonian (Portland), Apr. 29, 1876, p. 1.

36 Atlanta Constitution, May 19, 1876, p. 2. 
His common-man touches may have gained for Dom Pedro widespread popularity among Americans who loathed formal ceremony and discovered to their surprise that here was a king who felt the same way. But the rebuff to Secretary Fish may have precipitated an unforeseen problem for Dom Pedro in an area where he hoped to gain progress for his country during the trip-increased trade with the United States. It also raised the persistent issue of Brazilian slavery, a practice ended in the United States barely a dozen years earlier, after a costly civil war.

Four days after Dom Pedro landed in New York, Congress received a petition requesting that duties be set on all "slave-grown" products, including Cuban sugar and Brazilian coffee. One of the petitioners, Secretary of the Treasury Benjamin H. Bristow, suggested that duties would force Brazil to abolish slavery and, at the same time, strike against monarchy: "Duties would encourage coffee culture by our republican neighbors, Mexico and the Central American states, where it will be exchanged for our products." Such measures would "stimulate industry in Florida, Texas and Louisiana." He accused Brazil of profiting "from us immediately from the sale of the rapidly increasing product, the proceeds of which mainly go to purchase British goods." ${ }^{37}$ In essence, the two countries ruled by monarchs, the British Empire and Brazil, presently were helping one another at American expense, Bristow claimed.

In an interview, Secretary Fish said that he strongly favored the new tariff. Indeed Brazil was one of the most important powers still sanctioning slavery, he said, adding that there was no treaty requirement prohibiting such a tariff on their products. ${ }^{38}$ Dom Pedro's response to the proffered official reception may have had no effect on Secretary Fish's statements on this issue. The emperor may have known of the petition before he landed, or the secretary may have reached the conclusion months earlier. The timing, however, suggests that Dom Pedro's arrival may have precipitated the secretary's tariff remarks. ${ }^{39}$

${ }^{37}$ Quoted in New York. Times, Apr.19, 1876, p. 1. The petition, consisting of several letters to Congress, was referred to the House Ways and Means Committee. No action was taken on the request. See Congressional Record, 44th Cong., 1st Sess., Apr. 18, 1876, 2552.

38 New York Times, Apr. 19, 1876, p. 1. See also the Atlanta Constitution, Apr. 19, 1876, p. 2 , for a similar report.

${ }^{39}$ Fish's views on the issue are not noted in his biography, nor is there mention of Dom Pedro. See Allan Nevins, Hamilton Fish: The Inner History of the Grant Administration (New York, 1936); Fish's problems with U.S. minister to Brazil J. Watson Webb are summarized on pp. $249,642-46$. Webb apparently embezzled monies appropriated to reimburse Brazil for a U.S. claim for the ship Caroline. The issue encompassed questions of bribery of foreign officials, secret bank accounts, and deception of Congress. Nevins asserts that Webb never returned to the United States and, in fact, probably died in Brazil. A one-line newspaper account from April 1876, however, indicates that he did return and faced trial on the charges in Washington, D.C. The jury could not agree on Webb's guilt or innocence. Presumably, the 
Despite the tariff proposals, few newspapers editorialized extensively on Brazilian slavery. The San Francisco Chronicle agreed that Dom Pedro had been "a conscientious and consistent friend of emancipation," but slavery still existed in Brazil. "He has done all in his high power to abolish slavery in his empire," the paper noted, adding that "Indian boys can still be purchased there for a mere handful of trinkets." The Chronicle blamed slavery's continued presence in Brazil on the planters who "fight against the spirit of the Emancipation Act far more successfully than the 'white-liners' of Mississippi, Louisiana and Georgia fight against the reconstruction policy of our own government." A telling excuse for the practice by a West Coast newspaper illustrated the widespread disenchantment with Reconstruction at the time. The Chronicle declared, "A large proportion of the enslaved population of Brazil are far less fit for the responsibilities of freemen than were the most ignorant of the negroes in our Southern States." The paper concluded that, although the emperor had tried to abolish slavery, "actual emancipation must be the work of time, a work which will not be consummated in our generation." 40

Only a brief mention of slavery in Brazil was made by the Atlanta Constitution. In a six-stanza verse, a writer referred to Dom Pedro's antislavery views but cynically wondered whether the institution was responsible for Brazil's growth:

All the world has cheered your order,

Not a slave within your border.

All the world requires how was it

That you blent that mass composite

With no serf to wear a collar,

Pedro, gentleman and scholar.... ${ }^{41}$

The poem included references to the Brazilian practices of miscegenation, but the issue was not addressed by other newspapers. After all, racism

case was then dropped, which would account for the lack of an appeal or conviction record. Oddly, Dom Pedro was in the United States at the time of the trial. See Frank Leslie's Illustrated Newspaper, Apr. 29, 1876, p. 123. The cover of the issue, coincidentally, was the full-page portrait of Dom Pedro.

${ }^{40}$ San Francisco Chronicle, Apr. 26, 1876, p. 4. An earlier issue of the same paper addressed the emperor's abolitionist views: "[To have Brazil] conform to the requirements of the most advanced nations, he proceeded with a practical plan for the final extinction of slavery within his empire." Gradually, slavery was outlawed in Brazil, without resorting to civil war and with emancipation consistently supported by the emperor. For background on Dom Pedro's opposition to slavery and the slave trade, see Bethell, Cambridge History of Latin America, 3:724-43.

41"Brother Jonathan to Dom Pedro," Attanta Constitution, Apr. 27, 1876, p. 4. The author is not named. 
was taken for granted in all parts of the United States at the time. During Dom Pedro's visit to San Francisco, the Chronicle's pages contained numerous anti-Chinese references. Demonstrations against Asians occurred regularly, even while Dom Pedro was visiting the city. In an ironic twist, the Atlanta Constitution criticized San Francisco's anti-Chinese views by telling an apocryphal tale of a bedbug hitching a ride with Dom Pedro from Chicago. "[The bug] reached San Francisco in perfect safety. In the two days thereafter, the city was overrun and the inhabitants, attributing the plague to Chinese emigration, are loudly clamoring for the massacre of the Chow Chows." 42

Racism was only one political issue in 1876; the unfolding story of government graft dominated headlines. Democratic papers reveled in the disclosures, and many of their Republican counterparts expressed shock at the avarice displayed by members of their party. Dom Pedro must have been aware of the taint of scandal surrounding the Grant administration. During the week of the emperor's arrival, former secretary of war William Belknap's impeachment trial was underway, and the revelations of official corruption headlined most newspapers. ${ }^{43}$ President Grant was in the final year of his term, and the press was asking how much he knew about the shadowy activities that had transpired under his nose and why he had not tried to stop them. ${ }^{44}$

Dom Pedro's decision to travel unofficially probably was not influenced by the corruption investigations against.Grant administration officials. ${ }^{45}$ After all, the emperor had traveled to Europe in similar "incognito" fashion five years earlier. Nonetheless, Dom Pedro avoided injecting himself into the political thicket. The newspapers took notice of his hasty departure to the West two days after he landed in New York, giving the reason that he wished to avoid crossing the plains in the heat of the summer. He extended the trip into the Deep South, despite the oppressive weather, yet it was almost a month before the emperor paid a brief courtesy call to the White House. Nonetheless, at least one anti-Grant paper suggested Dom Pedro's hectic schedule was purposely set by the administration. "[The Grant administration's] true policy consists in keeping his [Dom Pedro's] attention

+2. Atlanta Constitution, May 16, 1876, p. 4.

${ }^{43}$ Dom Pedro read English. A Chicago Tribune reporter observed him reading a copy of the Tribune just before the reporter was introduced to him on the train. See Chicago Tribune, Apr. 20,1876, p. 8.

4See Frank Leslie's Illustrated Newspaper, May 6, 1876, p. 139, which questions how Grant could not have known about certain cotrupt actions being carried on by his cabinet officers and closest advisors.

${ }^{45}$ Williams, Dom Pedro the Magnanimous, 186, states that Dom Pedro began planning for a trip to the United States as early as 1872 . 
diverted from the newspaper accounts of Washington investigations, and of the indictment and impeachment of our administration officials." 46

Because 1876 was an election year, the emperor's travels could hardly avoid being mentioned in partisan political editorials. Editors watched the reactions of their democratically elected officials to the visiting monarch. Some then used the responses to either discredit political opponents or praise friendly politicians. Even before the emperor arrived, when the gala welcoming festivities were announced, the Atlanta Constitution, an anti-Grant administration newspaper, contrasted the planned welcome to the shabby reception given for the president-elect of Peru: "This chief of a sister republic was permitted to land in New York without receiving a single official civility from the Federal government. Dom Pedro is to be welcomed to our shores by the Secretary of State, but the Peruvian president was only welcomed by 'a committee representing the merchants in the Peruvian trade."' 47 When the official greeting miscarried, the Atlanta editor exaggerated some of the details, but indicated his admiration for the royal visitor's common ways. "Vive l'emperor," the headline read, with the information that by the time the official party-went to meet Dom Pedro, "he had long since landed at pier \#2, East River, and hired a cab to his hotel." 48

Dom Pedro's visit even figured into politics on the local level. For instance, the emperor opted not to stop when he passed through Chicago on the day of the city's mayoral election. The incumbent mayor was defeated, and the Chicago Tribune, the mayor's longtime editorial opponent, explained that the emperor was putting off a longer visit until he returned from the West. At that time, he would be spared the "clownishness" of the current mayor who by then would be out of office, the Tribune noted.49

In all regions of the country, but particularly in the West and the South, local newspapers usually adopted the role of the community's prime promoter. Stories about the emperor's travels offered a particularly convenient forum for an editor to brag about the benefits of his city by publishing any compliment the emperor may have made about the editor's hometown, even if the kind words were imaginary. The emperor's visits bolstered a city's sense of importance and gave it an unofficial ranking compared with competing towns. On the other hand, if Dom Pedro expressed disappointment

${ }^{46}$ Atlanta Constitution, Apr. 20, 1876, p. 2, quoting from the New York Telegram. Probably politics, not naiveté, restrained newspaper references to Brazil's constant problems with official corruption. The Webb case, well publicized nationally, suggested that Brazilian officials had been bribed with the money Webb was accused of embezzling. See Nevins, Hamilton Fish.

47 Atlanta Constitution, April 15, 1876, p. 2.

${ }^{48}$ Ibid., Apr. 16, 1876, p. 2.

${ }^{49}$ Cbicago Tribune, Apr. 18, 1876, p. 4. The article accused Chicago mayor H. D. Colvin of being "an embarrassment" when he "received other famous guests." 
with a town, one would not find a reference to it in the local press. Newspapers elsewhere happily published the criticism. "A Brazilian, well known to Dom Pedro, told the Post the emperor expressed much gratification with his reception in this city," the New York paper pointed out, still embarrassed at the numerous publicized faux pas in the initial greeting. ${ }^{50}$ The Chicago Tribune proudly quoted his high opinion of their town: "I never dreamed of finding such a city. It is finer than New York. It is a city of palaces. It is wonderful." 51 "Great men may as well not visit the United States at all if they don't come to San Francisco," the Chronicle crowed. "Two days of the snobbery and shoddy of that decaying metropolis [New York] sufficed for the emperor, and he then made haste to turn his steps toward the younger, brighter and more vigorous West." 52 Later, when Atlanta was added to his southern itinerary, the Atlanta Constitution reminded readers how certain it had been that he would make the change of plans: "How could he go home and say he had seen the wonders of America and yet have failed to come to Atlanta?" 5.3

Editors in smaller places out West, towns with little to advertise beyond the open spaces surrounding them, nonetheless used Dom Pedro's nonstop train passage through town to boast whatever advantage they believed their town had over its neighbors. For instance, the editor of the Sidney (Neb.) Telegraph noted that when Dom Pedro's train stopped briefly to take on water, the emperor told their reporter that he "would be here sometime in June and take our route to the [Black] Hills." -Cheyenne, Wyoming, 150 miles west, competed with Sidney as the "jumping off point" for the gold fields of Dakota. The Sidney paper noted, however, that Dom Pedro "said he would advise all persons going into the Hills to give Cheyenne a wide berth as the people there would steal the coppers off a dead [man's] eyes and kick him because they were not silver dollars." 54 The language sounds curiously un-imperial, and Dom Pedro probably never knew Cheyenne from any other western railroad town he passed through on the trip. As noted above, he was asleep. "[Dom Pedro] arrived here at 4:30 this morning. He didn't climb down out of his royal car and saunter about the city in search of sights, he was still dreaming of his far-off palaces when the train reached the Magic City," the Cheyenne Daily Leader reported. ${ }^{5}$

Dom Pedro's democratic travel methods caused many newspapers to point to what they inferred were his democratic principles of rule. The San

${ }^{50}$ New York Evening Post, Apr. 17, 1876, p. 4.

${ }^{51}$ Chicago Tribune, Apr. 22, 1876, p. 8.

52 San Francisco Cbronicle, Apr. 23, 1876, p. 4.

53 Atlanta Constitution, May 13, 1876, p. 2.

54 Sidney (Neb.) Telegraph, May 6, 1876, p. 3.

${ }^{55}$ Cheyenne Daily Leader, May 3, 1876. 
Francisco Cbronicle reviewed his vast intellectual interests and added: "We have noted but one weak spot in his intellectual armor, and that is not calculated to invite severe criticism at the hands of North American republicans." The paper quoted him as telling his countrymen, "If he could give his people the right to choose their own ruler, he would do so at once and if he lives long enough, he expects to make provision for the founding of a republic in Brazil." 56 "He is beyond doubt the most learned and liberal minded of all the sovereigns in the world," the Atlanta Constitution concluded. ${ }^{5}$ ?

But there are some lessons about American democracy that he needed to learn. One involved speaking aloud while court was in session, a practice for which he was rebuked by a Washington, D.C., judge. "Emperors must respect the proprieties of the courtroom as well as common people," the judge reportedly told him. The Atlanta Constitution repeated the story, approving of the judge's remarks. "And so they should," the editor agreed. ${ }^{58}$ Another paper suggested, however, that the emperor might change his view of how beneficial democracy might be for Brazil. "By the time he has seen us through the Belknap impeachment case, the presidential campaign, and familiarized himself with the Civil Service System," he may not think much of the democratic system, the San Francisco Chronicle wrote. ${ }^{99}$

Dom Pedro appears to have been less popular in much of the West and the South than on either coast. A Cheyenne, Wyoming, paper projected its own view on a buffalo that had knocked a train off the tracks just ahead of the emperor's train. "These western bulls have very little respect for rovalty," the editor wrote, "but this one seems not to have desired to injure the Emperor or he would have waited for the passenger train instead of butting the freight off the track." 60

The southern view probably had less to do with attitudes about royalty than it did about the people with whom the particular royal person chose to associate. Southerners, still recovering from the effects of the Civil War, probably noted that on his arrival to New York, the emperor asked to meet General William T. Sherman, hardly a well-liked figure in their region. ${ }^{61}$ His request to meet Sherman and several New England writers was widely quoted in other newspapers. When he attended the opening of the Centennial Exposition in Philadelphia, he was escorted by General Philip Sheridan and other Union veterans of the war. ${ }^{62}$ Southern editors commented that his trip

${ }^{56}$ San Francisco Chronicle, Apr. 24, 1876, p. 2.

57 Atlanta Constitution, Apr. 18, 1876, p. 1.

${ }^{58}$ Ibid., May 23, 1876, p. 2.

${ }^{59}$ San Francisco Cbronicle, Apr. 24, 1876, p. 2.

${ }^{60}$ Cheyenne Daily Leader, May 3, 1876, p. 3.

${ }^{61}$ New York. Times, Apr. 16, 1876, p. 1.

${ }^{62}$ Atlanta Constitution, May 11, 1876, p. 1. Dom Pedro's having accompanied army officers 
through the South seemed hurried in order for him to return for another visit to Boston and its former abolitionist intellectuals. Similar suspicions were evoked in Dixie when his critical remarks about New Orleans were widely quoted. ${ }^{63}$

Some newspapers hoped that the emperor's visit might bring mutual trade and immigration benefits for both countries. Several papers offered daily quotations for Brazilian coffee on market pages. ${ }^{64}$ None of the newspapers expected any Brazilians to move to the United States permanently. During May 1876, while the emperor was in the country, only two Brazilians, of some 12,300 immigrants that month, came to establish permanent residence. ${ }^{65}$ Dom Pedro, meanwhile, was "boostering" Brazil as a place where Americans could relocate, although few newspapers noted such statements. One paper, however, reported, "Dom Pedro invites in every way the better class of immigrants." 66 The "better class" was not defined, but no mention was made of the Confederate "exodus" to Brazil in the years following the Civil War. Nor did any paper remark on whether or not the emperor met with any of the hundreds of ex-Confederates who, disillusioned with Brazil, had subsequently returned to the United States. ${ }^{67}$

The San Francisco Chronicle reminded readers that ships carrying early settlers to California often put in to port at Rio de Janeiro, en route around Cape Horn to the gold fields. "The emperor has not been forgotten by these early voyagers... who visited the various parts of his empire...nor will they

to the ceremonies was mentioned in many papers, including the Washington Standard (Olympia), May 13, 1876, p. 3.

${ }^{63}$ Williams, Dom Pedro the Magnanimous, 201, 203, notes that Boston was his farorite city in America, while he was not favorably impressed with New Orleans or the rest of the South.

64See, for instance, Boston Evening Transcript, Apr. 20, 1876, p. 1: "Coffee at Rio, 61.50 reis per ten kilos"; New" York Times, Apr. 18, 1876, p. 4: "Rio coffee, 16 cents a pound for ordinary grade." On the West Coast, Central American coffee was probably much more common than Brazilian coffee. See San Francisco Chronicle, Apr. 22, 1876, p. 4: "Coffee: Central American, 19 1/2 to 21 cents; Java, 27 cents; Manila, 20 1/2 cents."

${ }^{65}$ The figures by country were printed in the Washington Standard, July 1, 1876, p. 2. The Nen York Times, Apt. 17, 1876, p. 4, described a man, apparently Brazilian, who missed seeing the emperor: "Abraham Deraisnes determined to participate in the serenade to Dom Pedro...last Saturday night, and becoming confused through liquor, he strayed into the 34 th Street Opera-house where he suddenly leapt on stage, drew a deputy sheriff's badge and club and announced he was arresting the performers." The piece concluded that Deraisnes was himself arrested. "The actresses were in great consternation." No explanation of the man's strange behavior, other than strong drink, was offered.

${ }^{66}$ Frank Leslie's Illustrated Nen'spaper, Apr. 29, 1876, p. 125.

${ }^{6} \mathrm{~A}$ summary of the Confederate emigration to Brazil may be found in Blanche Henry Clark Weaver, "Confederate Emigration to Brazil," Journal of Southern History, 27 (Feb. 1961): 33-53. A more recent work, highly favorable to the Confederates, contains numerous flaws in interpretation and appears to have been heavily dependent on folklore: Eugene C. Harter, The Last Colony of the Confederacy (Jackson, MS, 1985). Harter is a Brazilian-born descendant of ex-Confederates. 
forget the favors, privileges and courtesies he conferred on American citizens." The paper hinted that Americans may have abused such privileges from time to time: "It may be said that he allowed them the largest liberties, and it might be added that in a few cases, some of them took even more than they could have enjoyed in their own country with the same immunity." Unfortunately, the paper identified none of these old-timers by name, nor did it specify their alleged misdeeds while in Rio. ${ }^{68}$

Directly or indirectly, business people attempted to profit from the emperor's tour. A southern newspaper laughed at the seriousness with which various hat makers in New York attempted to sell expensive creations to the empress, who stayed in the East while the emperor toured the rest of the country. "The empress bought a $\$ 50$ bonnet at a Broadway millinery shop. This may seem of trivial importance to the outside world but to the denizens of Broadway in this special trade, it is of significance." The paper noted that the empress's decision caused "much jealousy and stinging invective" to issue forth from competing shops. ${ }^{69}$

Portrait makers vied for the chance to photograph Dom Pedro in their studios. "Bradley and Rulofson and Houseworth and Co. caught Pedro this morning and his photographs will soon be in the market," one paper noted. ${ }^{70}$ Other merchants, not as fortunate as to have direct royal endorsement, used either Dom Pedro's name or that of the empress in their advertising. Dom Pedro did not visit Portland, Oregon, but the following advertisement appeared in a local newspaper: "Should the emperor of Brazil visit Portland when he returns eastward, he may rely upon getting an outfit of the first quality at Fishel and Roberts. Dom had better try it, and he will never regret the outlay."71 An Atlanta shoe store advertised: "The empress can supply herself with a new stock of elegant shoes." 72

During his travels, Dom Pedro inspected technology, according to the papers, with an eye toward taking improved industrial methods back to his country. He spent many hours viewing the numerous devices on display at the Philadelphia exposition. "To avoid the crowds, the heat, and afternoon storms, he went to the grounds early, at times arriving before seven, and spent several hours there daily," biographer Mary Wilhelmine Williams wrote. ${ }^{73}$ During the afternoons, he traveled around Philadelphia, viewing zinc and iron works and other industrial sites. "His acquaintance with scientific objects is quite remarkable," one writer noted, adding that the emperor

${ }^{68}$ San Francisco Chronicle, Apr. 23, 1876, p. 1.

${ }^{69}$ Atlanta Constitution, May 12, 1876, p. 2.

${ }^{70}$ Oregonian (Portland), Apr. 28, 1876, p. 1.

${ }^{71}$ Ibid., May 2, 1876, p. 3.

72 Atlanta Constitution, May 30, 1876, p. 3.

${ }^{73}$ Williams, Dom Pedro the Magnanimous, 209. 
was a member of the prestigious French Academy of Sciences. The Philadelphia exposition seemed to be the ideal locale for satisfying his curiosity about the condition of American science. The writer emphasized that one reason for the emperor's visit was to put his country "on a footing equal in civilization and advancement of art to that of any country he has occasion to visit." The writer concluded, where else could American inventiveness be so efficiently viewed?74

On June 25, the then-obscure inventor Alexander Graham Bell waited to show Dom Pedro his new invention. It was a Sunday, and Bell needed to return to a teaching post in Boston that evening. As the emperor approached the exhibit next to Bell's, the inventor heard the guide say that he would view only that device before departing. Dom Pedro had met Bell earlier that month in Boston, and he recognized him. "How do you do, Mr. Bell? And how are the deaf-mutes of Boston?" the emperor asked, referring to having met Bell at the deaf school where he taught. Bell explained that he would have to return to Boston that evening and asked if the emperor could take a look now at Bell's new invention-the telephone. The emperor complied. Bell, standing 500 feet away, demonstrated the instrument, with Dom Pedro quoting Bell's words from Hamlet's soliloquy that he heard through the telephone. Over the course of the exhibition, the telephone became the greatest sensation. After Bell put the telephone on the market, "the Emperor of Brazil was one of the first to make practical use of it."75

The Brazilian emperor also looked at what are now less-celebrated types of machines. For example, Dom Pedro visited the shoe shop of Andre Cavilli, a San Francisco inventor "who has perfected what is supposed to be a valuable machine for the manufacture of boots and shoes." He ordered a model of the device "and volunteered to consult with his government about obtaining a patent for the inventor in Brazil, as he is desirous of introducing boot and shoe manufacturing business to his country." 76 Presumably, such manufacturing would eliminate any chance the Atlanta shoe shop might have had to tempt the empress to shop in Atlanta. In Boston, he visited the laboratory of a "Professor Robinson" who showed him "a wireless electric signal." 77 In Lowell, Massachusetts, he stopped to see "Dr. Ayer's medicine factory." 78

Dom Pedro enjoyed his visits with scientists, poets, and academicians. The Boston newspaper made mention of Dom Pedro's friendship with the late

\footnotetext{
${ }^{74}$ Norton, Frank Leslie's Historical Register of the Centennial Exposition, 301.

${ }^{75}$ The incident was widely described in contemporary newspapers. This account comes from Williams, Dom Pedro the Magnanimous, 210-11.

${ }^{76}$ Oregonian (Portland), Apr. 29, 1876, p. 1.

${ }^{77}$ Boston Evening Telegraph, June 14, 1876, p. 1.

${ }^{78}$ Ibid., June 8,1876, p. 1.
} 
Louis Agassiz and properly noted the emperor's visit to the scientist's grave. ${ }^{79}$ Agassiz's son, Alexander, dined with Dom Pedro and accompanied him to a number of Boston area institutions, including Harvard. ${ }^{80}$ During the tour, Dom Pedro visited a number of university campuses, including the University of California in Berkeley and the University of Cincinnati, where he inquired after a faculty member, a Dr. Murphy. "Dom Pedro had met him [Murphy] 23 years ago in Paris," the Cincinnati Gazette noted, "and during all that interval he had remembered not only the name of the doctor, but also that of the college with which he is connected." The paper concluded, "He looks like he wants to start his own medical college on the banks of the Amazon." 81 The paper did not explain how the meeting with Dr. Murphy had been possible given that Dom Pedro's only trip to Europe had taken place just five years before. Later, the emperor spoke at commencement ceremonies at Lehigh University and visited the "female academy" of Wellesley. ${ }^{82}$

Most newspapers approved of the emperor's interest in education. "He deplores greatly the lack of education among a large portion of his subjects. This defect he is laboring assiduously to remedy," Frank Leslie's reported.8. During his first two days in the United States, he inspected schools for the disadvantaged in New York as well as the aforementioned school for the deaf in Boston. ${ }^{84}$

Dom Pedro also visited a variety of religious institutions. He arrived in New York on Good Friday, and the royal party celebrated Easter at St.

${ }^{79}$ The celebrated scientist had died on Dec. 14, 1873, in Cambridge, Massachusetts. Agassiz, his wife, and a party of scientists had traveled through Brazil from April 1865 to June 1866. Dom Pedro took great interest in the expedition. "The fact that the Emperor of Brazil was deeply interested in all scientific undertakings, and had expressed a warm sympathy with my efforts to establish a great zoological museum in this country, aiding me even by sending collections made expressly under his order for the purpose, was an additional incentive," Agassiz, wrote in the preface of the posthumously published account of the trip; Louis and Elizabeth Agassiz, A Journey in Brazil, v.

${ }^{80}$ Several members of the Harvard faculty had been connected with the Agassiz expedition a decade earlier. However, the emperor did not meet only scientists during his U.S. risit. Williams tells of Dom Pedro's meetings with Whittier and other poets during his stay in Boston; see Williams, Dom Pedro the Magnanimous, 206. The story of the emperor translating Whittier's poems into Portuguese is told in the Boston Eiening Transcript, Apr. 17, 1876, p. 4.

${ }^{81}$ Cincinnati Gazette, quoted in Atlanta Constitution, May 27, 1876, p. 1.

${ }^{82}$ Boston Elening Transcript, June 14, 1876, p. 1.

${ }^{83}$ Frank Lestie's Illustrated Newspaper, Apr. 29, 1876, p. 125.

${ }^{84}$ Theodore Rooserelt, Sr., an important benefactor of one such New York school, accompanied the emperor to several New York primary and secondary schools. The father of the future president was then a forty-one-year-old partner in a prominent import firm. His seventeen-year-old son Theodore was preparing to enter Harvard in the fall. There is no record of young TR meeting Dom Pedro. For a detailed account of the tour, see New Yorte Times, Apr. 18, 1876, p. 7. For a portrait of the elder Roosevelt and a brief description of his philanthropy, see Edmund Morris, The Rise of Theodore Rooselelt (New York, 1979). 
Patrick's Cathedral. The same evening, he attended evangelist Dwight Moody's revival at New York's Hippodrome, seated on the platform next to the speaker. ${ }^{85}$ The Brazilian's visits to Jewish synagogues in San Francisco and New Orleans were widely reported. 86 In Salt Lake City, where his visit "was not productive of anything of startling interest," he attended Catholic mass in the morning and, in the afternoon, went to Mormon services in the Tabernacle. That night, he viewed a comedy at the local theater. "7 "He made many inquiries relative to the religious faith and practice of the Latter-Day Saints," the church-owned Deseret New's (Salt Lake City) said of his tour of the Mormon tabernacle. "From the nature of his interrogations and observations, he seemed to have given the history of the church some attentions," the paper concluded. 88

The newspaper description of Dom Pedro's tour of a Chinese joss house in San Francisco reveals as much the reporter's bias: "Here the emperor inspected minutely the Mongolian's venerated gods, and the absorbing curiosities which abound in the temple, strange enough to any one, and particularly, to him." The story continued, "The devout Chinaman's method of worship was explained, with its unaccountable ceremonies and cringing devotion to a set of wooden gods and a bunch of lighted punk." The paper concluded, "The emperor was greatly interested, but not more so than his companions, and retired wonderingly to the coach."89

The United States was a predominantly Protestant country in 1876 and, in many circles, Catholics were viewed with distrust. Most newspapers noted that Dom Pedro was "not an illiberal Catholic," pointing out that he favored separation of church and state. ${ }^{90}$ The labored differentiation illustrates how fond many newspapers had become of the touring monarch. Few United States newspapers were overtly negative about Brazil's emperor, while many lauded his matter-of-fact attitude, frank criticisms, and frequent complimentary remarks. By all accounts, his mission-to give citizens of the United States a positive impression of Brazil-was certainly fulfilled. ${ }^{91}$

\footnotetext{
${ }^{85}$ The elder Theodore Roosevelt sat on stage, too, next to the emperor and, apparently, described to him what some of the ceremonies meant. New York Times, Apr. 17, 1876, p. 5.

${ }^{86}$ He reportedly "surprised" the San Irancisco rabbis with his knowledge of Hebrew. San Francisco Cbronicle, Apr. 29, 1876, p. 4. Note his similar feat in a London synagogue five years earlier, reported in Williams, Dom Pedro the Magnanimous, 155.

${ }^{8}$ "The quote is from the dispatch from the "special correspondent" for the San Francisco Chronicle, Apr. 25, 1876, p. 4.

${ }^{88} 1$ )eseret $N e$ sus (Salt Lake City), Apr. 25, 1876, p. 2.

${ }^{89}$ San Francisco Cbronicle, April 29, 1876, p. 4.

${ }^{90}$ The quote is from the San Francisco Cbronicle, April 30, 1876, p. 4.

${ }^{91}$ Brazil suffered from bad press in the United States because of the slavery issue and the country's trade competition with American farmers. One odd case of a mythical Brazilian, so rich he offered to give away money, was described in an article headlined "Brazilian Wedding
} 
Dom Pedro's visit, the first by a reigning monarch of a major country, may have changed attitudes of some toward the institution of royalty. Certainly, he received generally enthusiastic and affectionate treatment from Americans. Even though he was a foreigner, a Catholic, an intellectual, and the ruler of a slaveholding society, Dom Pedro was able to gain the admiration of American newspapermen and their readers through his winning personality and unpretentious ways. Perhaps not all royal personages had to be like American recollections of King George III. But, in the hundredthanniversary year of independence from George III's rule, the view of Frank Leslie's editor was typical: "It is not at all probable that we shall ever take any stock in kings as a permanent investment, however wild we may be on the subject for the moment." Kings, queens, and emperors were celebritiescuriosities like European opera singers or Far Eastern mystics, whom Americans viewed as momentary diversions. Dom Pedro was a novelty, as the editor of Frank Leslie's noted, who "made a sensation for an hour, and then [his] day has passed."'92

In essence, the newspaper accounts about Dom Pedro's trip to the United States in 1876 reveal as much about how Americans viewed themselves as they do about how Americans felt about Dom Pedro. Racial and religious prejudices are apparent; so is the assurance of being part of a country on the move, the boosterism of an industrializing society. They wanted to show their first royal guest how great they were as a country; but each city and region also used the occasion to brag to competing sections. Yet, despite all the denials, mixed with the pride of democracy was a certain insecurity about not having an American royal counterpart. The closest person to an American emperor, the president, was Ulysses S. Grant, widely admired for his Civil War service and reviled for the corruption he seemed to counteHoax" in the Boston Evening Transcript, Apr. 27, 1876, p. 2: "Some months ago a bogus report was published of the marriage of DeSouza Cabral of Diamentina, Brazil, one of the richest and most extravagant men in the world. Begging letters accumulated at the New York Post Office, and the author of the hoax asked the post office to deliver them to him. The Postmaster General refused and the letters were returned to the writers. An average of twenty letters per week came into the New York office alone. The writers represented every condition in life; but while all parts of the Union were well represented, the South furnished the largest contingent."

${ }^{92}$ Frank Leslie's Illustrated Newspaper, Apr. 22, 1876, p. 106. See also Atlanta Constitution, May 21, 1876, p. 2: "Queen Emma, the Grand Duke Alexis, King Kalakaua and Dom Pedro are small fry beside the portly Queen of England, the Empress of India. She would receive a hearty welcome and among the centennial relics that we could show her would be a goodly lot of famous battlefields saved over from the days of 1776."

${ }^{93}$ E. Bradford Burns, A History of Brazil, 3rd ed. (New York, 1993), 223-24. As Burns notes, the emperor "quietly opposed slavery" almost from the beginning of his reign. In 1840 , he liberated all of his own slaves. He suggested gradual emancipation in 1864 and presented a plan in his speech from the throne in 1867. See also Bethell, Cambridge History of Latin America, 3:724-43. 
nance in his administration. In terms of celebrity, the ostentatious habits of the railroad barons and new industrialists provided an alternative to monarchy. Absent, however, was the dignity and assurance of a hereditary emperor like Dom Pedro.

But admiration was mutual. Dom Pedro's alien background and station might have suggested otherwise, but in many respects, he wanted what the United States already had. His American visit reconfirmed his opposition to the institution of slavery. With Dom Pedro's support, Brazil finally abolished slavery in $1888 .{ }^{93}$ If the emperor admired the institution of democta$\mathrm{cy}$ as it was practiced in America and the sense of equality that he felt among its people, he was ambivalent about both in Brazil. When his empire came to an end on November 15, 1889, Dom Pedro sailed to exile in Europe. He died in Paris on December 5, 1891, never having returned to the United States after his three-month tour made in the centennial of American independence. ${ }^{94}$

${ }^{94}$ For an account of the fall of the empire, see Charles Willis Simmons, Marshal Deodoro and the Fall of Dom Pedro II (Durham, NC, 1966). See also Harry Bernstein, Dom Pedro II (New York, 1973); and Bethel, Cambridge History of Latin America, 3:683-92. 